\title{
Heat Transfer and Physical-Mechanical Properties Analysis of Particleboard Produced with ZnO Nanoparticles Addition
}

\author{
Luana Cristal Lirya Silva, ${ }^{\mathrm{a}, *}$ Felipe Oliveira Lima, ${ }^{\mathrm{a}}$ Eduardo Chahud, ${ }^{\mathrm{b}}$ \\ André L. Christoforo, ${ }^{\mathrm{c}}$ Francisco A. Rocco Lahr, ${ }^{\mathrm{d}}$ Higor Rogério Favarim, ${ }^{\mathrm{e}}$ and
} Cristiane Inácio de Campos ${ }^{\mathrm{e}}$

\begin{abstract}
The use of particleboards (PB) has increased quickly as an alternative engineered wood product mainly due to its having a better ratio of resistance to weight and more elimination of wood defects, such as the presence of knots. Although the panel industry has been constantly growing, innovations are still necessary to improve the final product. The use of metallic oxide nanoparticles on the wood-based panels has the potential to increase the heat transfer process and improve the physicomechanical properties. The aim of this work was to evaluate the influence of the addition of zinc oxide $(\mathrm{ZnO})$ nanoparticles in $\mathrm{PB}$, correlating the physical and mechanical properties of the panel with the heat transfer process at $180^{\circ} \mathrm{C}$. The results were compared with the Brazilian standard ABNT NBR 14810-2 (2013) and the European standard EN 312 (2010), as well with works found in literature. The results showed a homogenous heat distribution during the pressing, which improved physical properties, decreasing the $24 \mathrm{~h}$ swelling from $22.2 \%$ to $14.9 \%$ and the $24 \mathrm{~h}$ absorption from $30.29 \%$ to $21.0 \%$. Besides that, MOR values was increased from 11.3 MPa to $14.5 \mathrm{MPa}$ and the MOE from $1880 \mathrm{MPa}$ to $2510 \mathrm{MPa}$.
\end{abstract}

Keywords: Particleboard; Physico-mechanical characteristics; Nanotechnology

Contact information: a: Department of Mechanical Engineering, São Paulo State University (UNESP), Avenida Ariberto Pereira da Cunha, Guaratinguetá, São Paulo 333 Brazil; b: Faculty of Engineering and Architecture, FUMEC University, Belo Horizonte, Brazil; c: Department of Civil Engineering, Federal University of São Carlos (UFSCar), São Carlos, Brazil; d: Department of Structures Engineering, Engineering School of São Carlos, University of São Paulo (EESC/USP), São Carlos, Brazil; e: São Paulo State University (UNESP), Campus of Itapeva, Rua Geraldo Alckmin, Itapeva, São Paulo 519 Brazil; *Corresponding author: Luana Cristal Lirya Silva (luana.cristal@unesp.br)

\section{INTRODUCTION}

The increasing use of wood products has prompted a more rational use of this raw material. One way that wood can be used advantageously is through the production of panels. Wood panels are produced for different applications in civil construction and furniture; one product, for example, is the particleboard (PB). Currently, PB is the most produced and most consumed wood panel in the world, representing approximately $50 \%$ of Brazil's panel production. Virtually all production is consumed by the domestic market, and PB exports are concentrated in South America, which in 2009 corresponded to $94.0 \%$ of total Brazilian PB exports (ABRAF 2013). These panel products are interesting alternatives to solid wood because in addition to their superior mechanical properties, they minimize wood defects such as knots, margins, and grain deviation, as well as the dimension limitations of wood, providing a more complete use of the raw material without compromising the quality of the final developed product. 
Despite the constant improvements in wood-based panels, some features can easily be improved by nanoparticles, which have unique physical and chemical properties than the same materials at larger scales (Yu et al. 2008). Nanoscale materials deeply penetrate the wood, which effectively changes the surface chemistry and may result in a higher protection against moisture, better heat conduction, and an increase in the physical and mechanical properties of wood composites (Mantanis and Papadopoulos 2010; Kumar and Kim 2012).

Table 1 presents some results of the main research found on the subject with panels MDP (Medium Density Particleboard) or PB, MDF (Medium Density Fiberboard) and OSB (Oriented Strand Board), and also shows the nanoparticle used and the result obtained.

Table 1. Main Works Found on The Topic

\begin{tabular}{|c|c|c|c|}
\hline Author & Nanoparticle & Panel & Results \\
\hline Pumadoulos (2010) & SurfaPoreTMW & $\begin{array}{c}\text { MDP, OSB e } \\
\text { MDF }\end{array}$ & $\begin{array}{c}\text { Improved in thickness } \\
\text { swelling. }\end{array}$ \\
\hline Salari et al. (2013) & Aluminum oxide & MDF & $\begin{array}{c}\text { Tendency of improvement of } \\
\text { physical and mechanical } \\
\text { properties and greater } \\
\text { workability of the panel. }\end{array}$ \\
\hline $\begin{array}{c}\text { Taghiyari } \\
\text { (2015) }\end{array}$ & Nanoparticles of Sílica & OSB & $\begin{array}{c}\text { Improved of Internal bonding } \\
\text { and heat conduction. }\end{array}$ \\
\hline $\begin{array}{c}\text { Rangavar and Hoseiny } \\
\text { (2015) }\end{array}$ & $\begin{array}{c}\text { Nanoparticles of } \\
\text { copper }\end{array}$ & MDP & $\begin{array}{c}\text { Improved water absorption } \\
\text { properties and thickness } \\
\text { swelling. }\end{array}$ \\
\hline $\begin{array}{c}\text { Cardoso et al. (2016) } \\
\text { Nanocellulose }\end{array}$ & MDP & $\begin{array}{c}\text { Increased MOR value and } \\
\text { improved internal bonding. }\end{array}$ \\
\hline
\end{tabular}

Regarding heat transfer in particulate panels, new probabilities have arisen with the use of nanoparticles. The addition of metallic nanoparticles in the resin increases the thermal conductivity of the wood panel, which can shorten the pressing time (Kumar et al. 2013).

Heat transfer plays an important role for the resin curing temperature in wood-based panels, acting from the surface of the panel to its center through the migration of the vapor. Thus, studying this phenomenon may contribute to the improvement of certain properties of the panel.

Some studies show that nanoparticles intensify the heat transference. Anoop et al. (2009) investigated the effect of different nanoparticle sizes on the heat transfer, observing that the nanofluids have high heat transfer capacity. Mohammed et al. (2018) used $\mathrm{ZnO}$ nanoparticles on wood composites to improve weather resistance and better physical and mechanical properties. In addition, Bak and Németh (2018) verified that zinc oxide provides effective protection against fungi, showing good protection for both investigated fungi, Coniophora puteana and Coriolus versicolor. These studies indicate that the use of nanoparticles in wood-based panels can be an interesting alternative to improve the heat transfer as well as the physic-mechanical properties of the panels.

The good resin fixation is responsible for appropriate properties of panels, so if a good heat transfer was achieved, then, the adhesive fixation is will be better. So, the $\mathrm{ZnO}$ can improves the heat transfer and the interaction between wood particles and resin whether the good adhesive fixation was achieved. 
Thus, aiming at a sustainable production, with lower temperature and pressing time, in this paper, the addition of zinc oxide nanoparticles, produced with a different method, a sol-gel process was examined to improve the performance of PB panels produced with urea-formaldehyde, especially in contact with water. This process is a promising method to get nanostructured powders in several ways, being a technological advance for panels and reveal an interesting alternative for the industry.

\section{EXPERIMENTAL}

\section{Particleboard Production}

The particles used to produce the panels were wood of Eucalyptus Urophila $x$ Grandis hybrid with dimensions of the particles sieved 9, 16, 35 and 60 mesh, donated by a timber company (Botucatu, Brazil). These particles were dried in an oven at $103{ }^{\circ} \mathrm{C} \pm 2$ ${ }^{\circ} \mathrm{C}$, until 3\% moisture content was obtained.

The adhesive used was urea-formaldehyde (UF) with a solids content of $66 \%$; its dosage was fixed based on the particles weight using $8 \%$ of adhesive for the internal layer and $10 \%$ of adhesive for the external layer. The catalyst contained ammonium sulfate and an emulsion of paraffin, with a solids content of $13.10 \%$ and $57.2 \%$, respectively. The panels were produced in two samples, without the addition of nanoparticles (T1) and with the addition of nanoparticles (T2). For the sample T2, 1\% of $\mathrm{ZnO}$ nanoparticles were added. The nanoparticles were synthesized by a sol-gel method (Favarim and Leite 2018).

For the particle mattress formation, $2000 \mathrm{~g}$ of wood particles were used in the proportion of $20 \%$ to $60 \%$ to $20 \%$, where $1200 \mathrm{~g}$ was for internal layer (9 and $16 \mathrm{mesh}$ ), $400 \mathrm{~g}$ for top layer and $400 \mathrm{~g}$ for bottom layer (35 and $60 \mathrm{mesh}$ ). The nanoparticles were added to the adhesive, and it was sprayed by an air spray gun onto the wood particles while they were mixed, ensuring good homogeneity. In all 12 panels of 45 x $45 \mathrm{~cm}$ were produced.

\section{Heat Transfer}

For the heat transfer study, a thermocouple type $\mathrm{K}$ was used, attached with an automated data acquisition system. The thermocouple was inserted into the internal layer of the mattress to measure the temperatures during the pressing.

After the particle mattress formation, it was pre-pressed at room temperature for $300 \mathrm{~s}$, and pressure of $0.3 \mathrm{MPa}$. A hot pressing with temperature of $180{ }^{\circ} \mathrm{C}$ and pressure of $4 \mathrm{MPa}$, resulting from the 235 bar hydraulic pressure applied to the pressure gauge, was performed with a total cycle of $600 \mathrm{~s}$, where was divided into three cycles of 3 minutes with 30 s break.

\section{Physical and Mechanical Tests}

The physical tests were performed to determine the density, moisture content, swelling in thickness, and water absorption after $2 \mathrm{~h}$ and $24 \mathrm{~h}$ immersion. To determine the mechanical properties, a bending test was performed to determine the modulus of elasticity (MOE) and the modulus of rupture (MOR). For the tests, 10 specimens were used for each one, as indicated by Brazilian standard ABNT NBR 14810-2 (2013).

\section{Determination of apparent density}

The density for each sample was determined using ten square specimens with 50 mm sides and was calculated using Eq. 1. The width and length were measured with a 
caliper, the thickness was measured in five different points (four corners and at the center) with a micrometer within $0.001 \mathrm{~mm}$ of precision, and the mass was determined using a precision scale,

$$
D=\frac{\mathrm{m}}{\mathrm{w} \times \mathrm{l} \times \mathrm{t}} \times 1,000,000
$$

where $D$ is the apparent density $\left(\mathrm{kg} \times \mathrm{m}^{-3}\right), m$ is the mass of the specimen $(\mathrm{g}), w$ is the width $(\mathrm{mm}), l$ is the length $(\mathrm{mm})$, and $t$ is the thickness $(\mathrm{mm})$.

\section{Determination of moisture content}

Each sample moisture content was determined using ten square specimens with 50 $\mathrm{mm}$ sides and their initial mass was determined with a precision scale. Samples were dried in a laboratory oven at $103{ }^{\circ} \mathrm{C} \pm 2{ }^{\circ} \mathrm{C}$ until they reached a constant mass (i.e., the fluctuation between mass measurements was less than $0.1 \%$ ). The sample moisture content was calculated by Eq. 2,

$$
U=\frac{m_{i} \times m_{d}}{m_{i}} \times 100
$$

where $U$ is the moisture content $(\%), m_{i}$ is the initial mass of the specimen $(\mathrm{g})$, and $m_{d}$ is the dried mass of the specimen $(\mathrm{g})$.

\section{Determination of thickness swelling and absorption}

Ten square specimens with dimensions of $50 \mathrm{~mm} \times 50 \mathrm{~mm}$ were completely submerged in water to determine the thickness swelling and absorption. The thickness swelling was determined by observing any increase in the thickness dimensions after the specimens were soaked in water for $24 \mathrm{~h}$, measured by a micrometer with a precision of $0.001 \mathrm{~mm}$. The water had a constant temperature of $25^{\circ} \mathrm{C}$ and a $\mathrm{pH}$ of 7 during the test. The same procedure was carried out to determine the absorption. The thickness swelling and the absorption were determined using Eqs. 3 and 4, respectively,

$$
\begin{aligned}
& T S=\frac{t_{s} \times t_{i}}{t_{i}} \times 100 \\
& A=\frac{a_{s} \times a_{i}}{a_{i}} \times 100
\end{aligned}
$$

where $T S$ is the thickness swelling $(\%), t_{s}$ is the specimen thickness after water soaking $(\mathrm{mm})$, and $t_{i}$ is the initial thickness $(\mathrm{mm}) ; A$ is the thickness absorption (\%), $a_{s}$ is the absorption after the water soaking $(\mathrm{mm})$, and $a_{i}$ is the initial absorption (mm).

\section{Determination of elasticity modulus and rupture modulus}

The bending test was used to obtain the modulus of elasticity (MOE) and modulus of rupture (MOR). The test was performed on a universal testing machine (EMIC Hidralmac, Araraquara, Brazil), with a sample placed over two supports and with the distance between supports being 20 times the thickness of the specimen, as shown in Fig. 1 . 


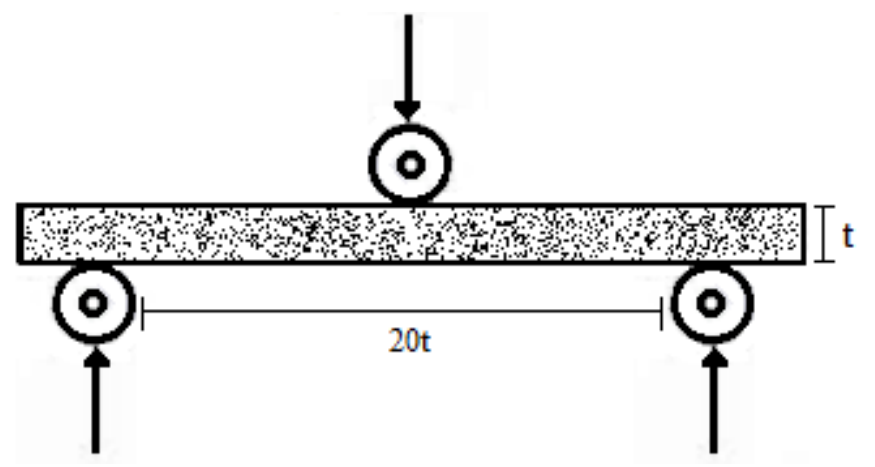

Fig. 1. Distance between supports adapted from ABNT NBR 14810-2 (2013)

The MOR values were obtained using Eq. 5, and the MOE values were obtained with Eq. 6. These equations were added to the software that accompanies the universal testing machine. Equation 5 is shown below,

$$
M O R=\frac{1.5 \times \mathrm{L} \times \mathrm{D}}{\mathrm{w} \times \mathrm{t}^{2}}
$$

where $M O R$ is the modulus of rupture $(\mathrm{MPa}), L$ is the read rupture load $(\mathrm{N}), D$ is the distance between supports $(\mathrm{mm}), W$ is the specimen width $(\mathrm{mm})$, and $t$ is the average thickness taken at three points on the specimen $(\mathrm{mm})$. Equation 6 is shown below,

$$
M O E=\frac{\mathrm{L}_{1} \times \mathrm{D}_{3}}{4 \times \mathrm{d} \times \mathrm{W} \times \mathrm{E}_{3}}
$$

where $M O E$ is the modulus of elasticity $(\mathrm{MPa}), L_{l}$ is the load on the proportional limit $(\mathrm{N})$, $D$ is the distance between the supports of the appliance $(\mathrm{mm}), d$ is the deflection corresponding to the load $\mathrm{P}_{1}(\mathrm{~mm}), W$ is the specimen width $(\mathrm{mm})$, and $E$ is the average thickness taken at three points on the specimen $(\mathrm{mm})$.

\section{Internal bonding - Perpendicular traction}

The internal bonding test was performed with a perpendicular traction of the panel, where the specimen was assembled with a $50 \mathrm{~mm} \times 50 \mathrm{~mm}$ controlled velocity extension. The calculation of the resistance was done perpendicularly through Eq. 7, and that was added to the software used with the universal testing machine. Equation 7 is shown below,

$$
T P=\frac{\mathrm{L}}{\mathrm{S}}
$$

where $T P$ is the perpendicular tensile strength $(\mathrm{MPa}), L$ is the burst load $(\mathrm{N})$, and $S$ is the surface area of the specimen $\left(\mathrm{mm}^{2}\right)$.

\section{Statistical Analysis}

Statistical analyzes were performed with $\mathrm{R}$ version 3.2.0 software (www.rproject.org), by Test $\mathrm{T}$ with significance levels of 5\%. It was tested in two samples, the sample 1 (T1) had no added nanoparticles, and sample 2 (T2) had 1\% of nanoparticles added. After the tests, the results were compared with the test standards ABNT NBR 14810 (2013) and EN 312 (2010). 


\section{RESULTS AND DISCUSSION}

\section{Physical Properties}

Tables 2 to 7 presents the average results obtained for the physical tests of density, moisture content, thickness swelling, and absorption for all specimens. The results were within the normative specifications proposed by the Brazilian standard - ABNT NBR 14810 (2013) and the European standard (EN) - EN 312 (2010).

Table 2. Average Density $\left(\mathrm{Kg} / \mathrm{m}^{3}\right)$

\begin{tabular}{|c|c|c|c|c|}
\hline \multirow{2}{*}{ Condition } & T1 & T2 & ABNT & EN \\
\hline & $0 \%$ & $1 \%$ & $0 \%$ & $0 \%$ \\
\hline Mean ${ }^{1}$ & 599.96 & 676.57 & $551-750$ & $500-800$ \\
\hline $\mathrm{SD}^{2}$ & 67.41 & 50.34 & - & - \\
\hline$(\% C V)^{3}$ & 11.23 & 7.44 & - & - \\
\hline P-value & \multicolumn{4}{|c|}{0.000675457} \\
\hline${ }^{* 1}$ Means $(\mathrm{Te}$ & $.05) ;{ }^{2}$ & ionc & ; ${ }^{3}$ Coefficie & iance $(\% \mathrm{C}$ \\
\hline
\end{tabular}

The average density increased after the addition, and with $\mathrm{P}$-value 0.0067 was obtained statistical difference for Test $\mathrm{T}$, with 5\% significance. This occurred because of a decreased average thickness. Therefore, the higher density of the panels, especially the external layers, in T2 was due to the acceleration of the heat transfer provided by the nanomaterials, which provided a smaller thickness and increased the density.

Table 3. Moisture Content (\%)

\begin{tabular}{|c|c|c|c|c|}
\hline \multirow{2}{*}{ Condition } & T1 & T2 & ABNT & EN \\
\hline & $0 \%$ & $1 \%$ & $0 \%$ & $0 \%$ \\
\hline Mean ${ }^{1}$ & 6.45 & 6.61 & $5-11 \%$ & - \\
\hline SD $^{2}$ & 0.51 & 0.58 & - & - \\
\hline$(\% C V)^{3}$ & 7.91 & 8.77 & - & - \\
\hline P-value & & & & \\
\hline
\end{tabular}

For moisture content, with P-value 0.45 , there was no statistical difference between the samples for Test $\mathrm{T}$ with 5\% significance. Therefore, it was concluded that the moisture content did not interfere with the other properties. When compared with other studies, the panels examined in this study remained in the same mean values. Valle (2015) studied PB with the addition of silica $\left(\mathrm{SiO}_{2}\right)$ nanoparticles and found an average density value of 866 $\mathrm{kg} / \mathrm{m}^{3}$ and moisture content values of $6.95 \%$ and $6.46 \%$ for PB panels without nanoparticles and $4 \%$ of $\mathrm{SiO}_{2}$, respectively, similar values for this work. Cardoso et al. (2016) obtained moisture content values of $9.7 \%$ and $10.8 \%$ with the addition of $2 \%$ of nanocellulose and 5\% of nanocellulose, respectively, in agglomerated panels made with urea-formaldehyde resin. The use of $\mathrm{ZnO}$ nanoparticles allowed for values that were in accordance with the Brazilian standard during the $2 \mathrm{~h}$ and $24 \mathrm{~h}$ swelling tests. However, the T1 panels presented higher swelling for both tests with statistical difference in Test $\mathrm{T}$ and 5\% significance. Roumeli et al. (2012) and Valle (2015) both treated the PB panels with silica nanoparticles. Both studies show an improvement for the swelling during the 24 $\mathrm{h}$ test, obtaining values of $29 \%$ and $27 \%$ and $62 \%$ and $36 \%$, respectively, for panels without and with the addition of the nanomaterial. 
Table 4. $2 \mathrm{~h}$ Thickness Swelling (\%)

\begin{tabular}{|c|c|c|c|c|}
\hline \multirow{2}{*}{ Condition } & T1 & T2 & ABNT & EN \\
\hline & $0 \%$ & $1 \%$ & $0 \%$ & $0 \%$ \\
\hline Mean 1 & 10.60 & 4.30 & $<8 \%$ & $<12 \%$ \\
\hline $\mathrm{SD}^{2}$ & 1.60 & 1.03 & - & - \\
\hline$(\% C V)^{3}$ & 15.09 & 23.95 & - & - \\
\hline P-value & & & & \\
\hline
\end{tabular}

Table 5. 24h Thickness Swelling (\%)

\begin{tabular}{|c|c|c|c|c|}
\hline \multirow{2}{*}{ Condition } & T1 & T2 & ABNT & EN \\
\cline { 2 - 5 } & $0 \%$ & $1 \%$ & $0 \%$ & $0 \%$ \\
\hline \multirow{2}{*}{ Mean ${ }^{1}$} & 22.20 & 14.90 & $<18 \%$ & $<16 \%$ \\
\hline SD $^{2}$ & 1.70 & 1.50 & - & - \\
\hline (\%CV) $^{3}$ & 7.66 & 10.07 & - & - \\
\hline P-value & \multicolumn{4}{|c|}{0.01822358} \\
\hline${ }^{*}{ }^{2}$ Means (Test t, $\left.\alpha=0.05\right) ;{ }^{2}$ Standard deviation of the data; ${ }^{3}$ Coefficient of Variance (\%CV) \\
\hline
\end{tabular}

Table 6. 2 h Absorption (\%)

\begin{tabular}{|c|c|c|c|c|}
\hline \multirow{2}{*}{ Condition } & T1 & T2 & ABNT & EN \\
\cline { 2 - 5 } & $0 \%$ & $1 \%$ & $0 \%$ & $0 \%$ \\
\hline \multirow{2}{*}{ Mean ${ }^{1}$} & 9.24 & 5.78 & - & - \\
\hline SD $^{2}$ & 1.60 & 1.25 & - & - \\
\hline$(\%$ CV) & \\
\hline P-value & 17.31 & 21.62 & - & - \\
\hline${ }^{*}{ }^{3}$ Means (Test $\left.t, \alpha=0.05\right) ;{ }^{2}$ Standard deviation of the data; ${ }^{3}$ Coefficient of Variance (\%CV) \\
\hline
\end{tabular}

Table 7. 24h Absorption (\%)

\begin{tabular}{|c|c|c|c|c|}
\hline \multirow{2}{*}{ Condition } & T1 & T2 & ABNT & EN \\
\cline { 2 - 5 } & $0 \%$ & $1 \%$ & $0 \%$ & $0 \%$ \\
\hline \multirow{2}{*}{ Mean ${ }^{1}$} & 30.29 & 21.01 & - & - \\
\hline SD $^{2}$ & 3.35 & 1.17 & - & - \\
\hline (\%CV) $^{3}$ & 11.06 & 5.57 & - & \\
\hline P-value & \multicolumn{5}{|c|}{0.00654103} \\
\hline${ }^{* 1}$ Means (Test $\left.t, \alpha=0.05\right) ;{ }^{2}$ Standard deviation of the data; ${ }^{3}$ Coefficient of Variance $(\% C V)$ \\
\hline
\end{tabular}

Similarly as thickness swelling, the absorption test presented good values for the panels treated with $\mathrm{ZnO}$ nanoparticles. When comparing the $\mathrm{T} 1$ and $\mathrm{T} 2$ for the $2 \mathrm{~h}$ water absorption test, there was an approximate decrease of 50\%. Statistical difference was also obtained in the Test $t$, with 5\% of significance.

Despite the absence of normative data for the absorption test, recent studies show verified higher values for both the $2 \mathrm{~h}$ and $24 \mathrm{~h}$ absorption tests. Surdi (2015) has data that reaches approximately $66 \%$ and $84 \%$, making use of eucalyptus residues for $2 \mathrm{~h}$ and $24 \mathrm{~h}$ tests, respectively. Cardoso et al. (2016) has data that reaches $180 \%$ and $220 \%$, making use of $2 \%$ of nanocellulose and $5 \%$ of nanocellulose for the $24 \mathrm{~h}$ absorption tests. 
These results reinforce the quality of the produced panel in this study as well as demonstrate that the use of $\mathrm{ZnO}$ nanoparticles may better cure the resin, which increased the internal adhesion among the particles of the panel, preventing higher water absorption and swelling in PB panels.

\section{Mechanical Properties}

Table 7 to 9 presents the average results obtained for the mechanical tests of Modulus of Rupture, Modulus of Elasticity and Internal Bond, for all specimens. The results were within the normative specifications proposed by the Brazilian standard ABNT NBR 14810 (2013) and the European standard (EN) - EN 312 (2010).

Table 8. Modulus of Elasticity - MOE (MPa)

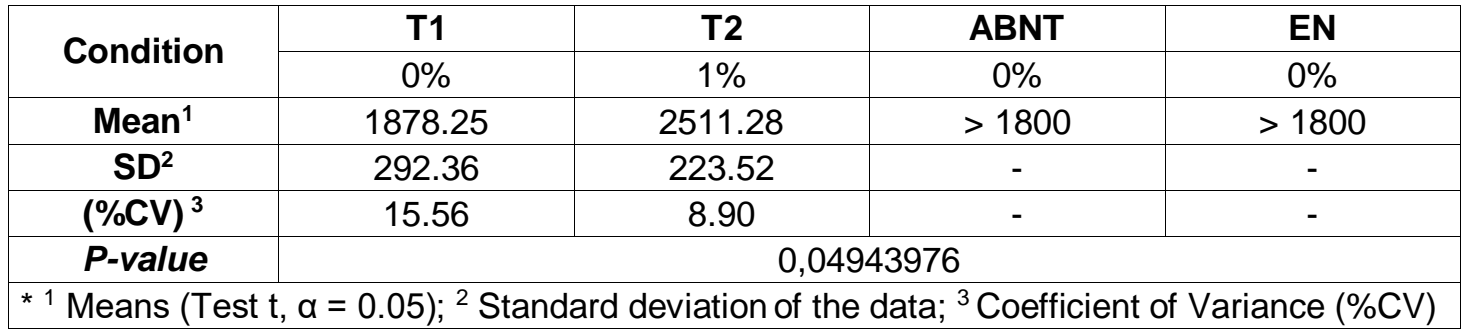

The Brazilian standard - ABNT NBR 14810 (2013) and the European standard (EN) - EN 312 (2010) specify a minimum value of $1800 \mathrm{MPa}$ for the modulus of elasticity (MOE), considering non-structural panels with a thickness of $6 \mathrm{~mm}$ to $13 \mathrm{~mm}$. All samples were in accordance with the standards; however, for T2, the MOE values increased more than $20 \%$ and obtained statistical difference for Test $\mathrm{T}$ with $5 \%$ of significance.

Table 9. Modulus of Rupture - MOR (MPa)

\begin{tabular}{|c|c|c|c|c|}
\hline \multirow{2}{*}{ Condition } & T1 & T2 & ABNT & EN \\
\cline { 2 - 5 } & $0 \%$ & $1 \%$ & $0 \%$ & $0 \%$ \\
\hline Mean ${ }^{1}$ & 11.32 & 14.52 & $>11$ & $>11$ \\
\hline SD $^{2}$ & 2.08 & 1.56 & - & - \\
\hline$\left(\%\right.$ CV) ${ }^{3}$ & 18.37 & 10.74 & - & - \\
\hline $\boldsymbol{P}$-value & \multicolumn{4}{|c|}{0,01215903} \\
\hline${ }^{*}{ }^{1}$ Means (Test t, $\left.\alpha=0.05\right) ;{ }^{2}$ Standard deviation of the data; ${ }^{3}$ Coefficient of Variance (\%CV) \\
\hline
\end{tabular}

All samples tested for rupture stress satisfied both ABNT NBR 14810 (2013) and EN 312 (2010). The modulus of rupture (MOR) for the ABNT NBR 14810 (2013) indicates a minimum value of $11 \mathrm{MPa}$, while the MOR for the European standard is $11.5 \mathrm{MPa}$. The addition of $\mathrm{ZnO}$ nanoparticles increased the MOR values, which increased the performance of the PB panels.

The mean values for the MOR of the different samples presented a statistical significant difference with 95\% confidence, where T2 presented better results. Valle (2015) found MOR values close to 12.2 MPa. Taghiyari (2011) studied PB panels with the addition of copper nanoparticles and found MOR values between 11.6 MPa and 12.2 MPa, which agrees with the values found in this research. 
Table 10. Internal Bond (MPa)

\begin{tabular}{|c|c|c|c|c|}
\hline \multirow{2}{*}{ Condition } & T1 & T2 & ABNT & EN \\
\cline { 2 - 5 } & $0 \%$ & $1 \%$ & $0 \%$ & $0 \%$ \\
\hline Mean ${ }^{1}$ & 0.44 & 0.46 & $>0.4$ & $>0.4$ \\
\hline SD $^{2}$ & 0.06 & 0.05 & - & - \\
\hline$(\% \text { CV })^{3}$ & 13.64 & 10.87 & - & - \\
\hline $\boldsymbol{P}$-value & \multicolumn{5}{|c|}{0,8985573} \\
\hline${ }^{*}{ }^{3}$ Means (Test t, $\left.\alpha=0.05\right) ;{ }^{2}$ Standard deviation of the data; ${ }^{3}$ Coefficient of Variance $(\% C V)$ \\
\hline
\end{tabular}

The analysis of the internal bond obtained by the perpendicular traction test for the produced panels presented similar values and had no statistical difference between them with Test $t$ and 5\% of significance. All the obtained results were in accordance with the values established by the Brazilian standard and the European standard, as well as other published papers. Taghiyari (2011) added copper nanoparticles to PB panels and obtained approximate values of $0.48 \mathrm{MPa}$.

The performance increased with the addition of $1 \%$ of $\mathrm{ZnO}$ nanoparticles to the production of $\mathrm{PB}$ panels when analyzing the MOR, MOE, and internal bonding.

\section{Heat Transfer}

The pressing temperature of the panels was analyzed during a hot pressing by a type $\mathrm{k}$ thermocouple because curing the resin could have been affected by the addition of the $\mathrm{ZnO}$ nanoparticles. As shown in Fig. 2, there was an evolution of the temperature during the pressing process for both $\mathrm{T} 1(0 \%)$ and $\mathrm{T} 2(1 \%)$.

The addition of $\mathrm{ZnO}$ nanoparticles on the $\mathrm{PB}$ panel induced less variation on the temperature over time during the hot pressing, as shown by the T2 line. T1 slowly increased the temperature and presented some oscillation. The final temperature for T2 was obtained at approximately $220 \mathrm{~s}$, while the $\mathrm{T} 1$ needed approximately $380 \mathrm{~s}$ to reach its final temperature.

As shown in Fig. 1, the addition of nanoparticles accelerated the heating and curing process of the panel in the innermost region. In the first cycle (up to $180 \mathrm{~s}$ ), T2 had already reached $100{ }^{\circ} \mathrm{C}$ while the $\mathrm{T} 1$ during this period was still approximately $85^{\circ} \mathrm{C}$. The curing urea-formaldehyde (UF) temperature should be between $95^{\circ} \mathrm{C}$ and $130{ }^{\circ} \mathrm{C}$ (Iwakiri 2005).

Achieving the needed cure temperature while in the first cycle provided better densification and material compacting, which resulted in a higher density and smaller voids. The higher density and smaller voids improved the panels performance when in contact with water, reducing the swelling in thickness and the water absorption. For the mechanical properties, the higher densification provided better mechanical properties, especially in the strength results and the rigidity of the panels, obtained from the bending test. For the internal bond test, there was no significant statistical difference because the final cure temperature was approximately the same for both samples.

The graph presented on Fig. 2 shows that the internal temperature for T2 was reached at $180 \mathrm{~s}$ and remained nearly constant up to $600 \mathrm{~s}$. These results suggest that future studies use reduced press cycles, aiming for less pressing time, generating increased production, and lower energy consumption. Lima et al. (2018) indicate that pressing times between $400 \mathrm{~s}$ and $600 \mathrm{~s}$ do not present differences in the physical and mechanical properties of the panels. Additionally, the nanoparticles' association can further reduce this pressing time without compromising the final technical performance of the panel.

Although the highest temperature on the plates of the press was $180{ }^{\circ} \mathrm{C}$, the 
maximum temperature reached within the panels was approximately $120{ }^{\circ} \mathrm{C}$ for both panels. However, T2 constantly increased the temperature, prevented major oscillations, reached its final temperature way before $\mathrm{T} 1$, and accelerated the resin cure.

Simple changes and with low-cost might allow for a shorter pressing time, a decreased pressing temperature, or both, keeping the same quality of the PB panels. Similar results were achieved by Kumar et al. (2013), with the addition of $\mathrm{Al}_{2} \mathrm{O}_{3}$ nanoparticles in wood panels that verify an increase in the panel properties.

By improving the temperature distribution in the PB panels during the pressing, with the addition of the $\mathrm{ZnO}$ nanoparticles, it was possible to study different ways of optimizing the pressing cycle variables, allowing for both a shorter pressing time and a decrease in the pressing temperature. In addition, the wood particles and the resin, which define the physical and mechanical properties, had better interactions with each other.



Fig. 2. Curves of temperature with addition (T2) and no addition (T1) of nanoparticles in core layer during pressing

\section{CONCLUSIONS}

1. The addition of $1 \%$ of $\mathrm{ZnO}$ nanoparticles to particleboard (PB) showed an increase in the mechanical and physical properties, especially for swelling and water absorption. These are considered critical properties for PB panels.

2. Despite the $\mathrm{T} 1$ and $\mathrm{T} 2$ reaching the same final temperatures, the treated panels (T2) gradually increased in temperature, reaching its final temperature before the nontreated panels (T1). This phenomenon accelerated the cure of the resin, allowing for a better interaction between the wood particles and improving the physic-mechanical properties of the panels.

3. Since the heat transfer was improved and the good adhesive fixation was achieved, a better interaction between wood particles and the resin was achieved. This characteristic also improved the water absorption and swelling because empty spaces between wood particles were smaller. 
4. Using a small amount of $\mathrm{ZnO}$ nanoparticles improved the quality of the panel. This was a simple and low-cost implementation and is promising when considering the thermal energy efficiency and lower production costs.

\section{ACKNOWLEDGMENTS}

The authors are grateful for the financial support from grant 2016/23936-0 São Paulo Research Foundation (FAPESP), and for the support and coordination from the Improvement of Higher Education Personnel (CAPES).

\section{REFERENCES CITED}

ABRAF (2013). "Yearbook statistical of ABRAF," Associação Brasileira de Produtores de Florestas Plantadas, Brasília, pp. 149.

Anoop, K. B., Sundararajan, T., and Das, S. K. (2009). "Effect of particle size on the convective heat transfer in nanofluid in the developing region," International Journal of Heat and Mass Transfer 52(9-10), 2189-2195. DOI:

10.1016/j.ijheatmasstransfer.2007.11.063

ABNT NBR 14810-1 (2013). "Chapas de madeira aglomerada: Terminologia," Associação Brasileira de Normas Técnicas, Rio de Janeiro, Brasil.

ABNT NBR 14810-2 (2013). “Chapas de madeira aglomerada: Requisitos,” Associação Brasileira de Normas Técnicas, Rio de Janeiro, Brasil.

ABNT NBR 14810-3 (2013). "Chapas de madeira aglomerada: Métodos de ensaio," Associação Brasileira de Normas Técnicas, Rio de Janeiro, Brasil.

Bak, M., and Németh, R. (2018). "Effect of different nanoparticle treatments on the decay resistance of wood," BioResources 13(4), 7886-7899. DOI: 10.15376/biores.13.4.7886-7899

Cardoso, G.V., Teixeira, F. P., and Ferreira, E. S. (2016). "Nanocelulose como catalisador de ureia-formaldeido para produção de paineis aglomerados [Nanocellulose as a urea-formaldehyde catalyst for the production of agglomerated panels]," in: Anais do XV Ebramem, Curitiba, Paraná, Brasil, pp. 1-9.

EN 312 (2010). "Particleboard - Specifications - Part 2: Requirements for general purpose boards in dry environments," European Committee for Standardization, Brussels, Belgium.

Favarim, H. R. and Leite, L. O. (2018). "Performance of $\mathrm{ZnO}$ nanoparticles for fire retardant and UV protection of pine wood," BioResources 13(3), 6963-6969. DOI: 10.15376/biores.13.3.6963-6969

Iwakiri, S. (2005). "Painéis de madeira reconstituída," Curitiba, Brasil, pp. 247.

Kumar, B., and Kim, S. W. (2012). "Energy harvesting based on semiconducting piezoelectric ZnO nanostructures," Nano Energy 1(3), 342-355. DOI: 10.1016/j.nanoen.2012.02.001

Kumar, A., Gupta, A., Sharma, K. V., and Gazali, S. B. (2013). "Influence of aluminum oxide nanoparticles on the physical and mechanical properties of wood composites," BioResources. 8(4), 6231-6241. DOI: 10.15376/biores.8.4.6231-6241

Lima, F. O., Silva, L. C. L., Campos, C. I., Christoforo, A. L., Lahr, F. A. R. (2018). "Pressing time influence on physical and mechanical properties of MDP panels," 
Scientia Forestalis 46(119), 387-393. DOI: 10.18671/scifor.v46n119.06

Mantanis, G. I., and Papadopoulos, A. N. (2010). "Reducing the thickness swelling of wood based panels by applying a nanotechnology compound," European Journal of Wood and Wood Products 68(2), 237-239. DOI: 10.1007/s00107-009-0401-6

Mohammed, M., Rozyanty, R., Mohammed, A. M., Osman, A. F., Adam, T., Dahham, O. S., Hashim, U., Noriman, N. Z., and Betar, B. O. (2018). "Fabrication and characterization of zinc oxide nanoparticle-treated kenaf polymer composites for weather resistance based on a solar UV radiation," BioResources 13(3), 6480-6496. DOI: 10.15376/biores. 13.3.6480-6496

Rangavar, H. and Hoseiny, M. F. (2015). "The effect of nanocopper additions in a ureaformaldehyde adhesive on the physical and mechanical properties of particleboard manufactured from date palm waste," Mechanics of Composite Materials 51(1), 119126. DOI: 10.1007/s11029-015-9482-y.

Roumeli, E., Papadopoulous, E., Pavlidou, E., Vourlias, G., Bikiaris, D., Paraskevopoulos, K. M., and Chrissafis, K. (2012). "Synthesis, characterization and thermal analysis of urea-formaldehyde/nanoSiO ${ }_{2}$ resins," Thermochimica Acta 527(12), 33-39. DOI: 10.1016/j.tca.2011.10.007

Salari, A., Tabarsa, T., Khazaeian, A., Saraeian, A. (2013). "Improving some of applied properties of oriented strand board (OSB) made from underutilized low quality paulownia (Paulownia fortunie) wood employing nano-SiO 2 ," Industrial Crops and Products 42(1), 1-9. DOI: 10.1016/j.indcrop.2012.05.010

Surdi, P. G. (2015). Aproveitamento de Resíduos do Processamento Mecânico de Madeiras Amazônicas para a Produção de Painéis Aglomerados de alta Densificação. Ph.D. Dissertation, University of São Paulo, Piracicaba, Brasil.

Taghiyari, H. R. (2011). "Study on the effect of nano-silver impregnation on mechanical properties of heat-treated Poplus nigra," Wood Science and Technology 45(2), 399404. DOI: $10.1007 / \mathrm{s} 00226-010-0343-5$

Taghiyari, H. R., and Nouri, P. (2015). "Effects of nano-wollastonite on physical and mechanical properties of medium-density fiberboard," Maderas, Ciencia y tecnología, 17(4), 833-842. DOI: 10.4067/S0718-221X2015005000072

Valle, A. C. M. (2015). Análise das Propriedades Físicas e Mecânicas de Painéis MDP de Madeira de Eucalipto com Adição de Nanopartículas de Sílica ao Adesivo Uréiaformaldeído. Master's Thesis, São Paulo State University (UNESP), Itapeva, Brasil.

Yu, W., France, D. M., Routbort, J. L., Chol, S. U. S. (2008). "Review and comparison of nanofluid conductivity and heat transfer enhancements," Heat Transfer Engineering 29(5), 432-460. DOI: 10.1080/01457630701850851

Article submitted: January 22, 2019; Peer review completed: May 14, 2019; Revised version received: October 22, 2019; Accepted: October 23, 2019; Published: October 30, 2019.

DOI: 10.15376/biores.14.4.9904-9915 